\title{
Determination of Cocoa Powder Quality Produced by Small-Medium Enterprise Using Six Sigma Analysis
}

\author{
Hendy Firmanto $^{1 *}$, Yesi Kumalasari' ${ }^{2)}$, and Zikil Muarrofah ${ }^{3)}$ \\ ${ }^{1)}$ Indonesian Coffee and Cocoa Research Institute, Jl. PB Sudirman 90 Jember 68118, Indonesia \\ ${ }^{2}$ Agroindustial Management, Polytechnic of Jember, Jl. Mastrip, Jember 68121, Indonesia \\ ${ }^{3)}$ Faculty of Agriculture, University of Jember, Jl. Kalimantan 37 Kampus Tegalboto Jember 68121, Indonesia \\ ${ }^{*}$ )Corresponding author: hendy.firmant@gmail.com \\ Received: 25 August 2020 / Accepted: 08 October 2020
}

\begin{abstract}
Cocoa powder now has become a common craft product of small-medium processing enterprises (SME) in Indonesia. Small-medium enterprises develop processing sequence in smaller quantity compared to big company, nonetheless it must follow the national cocoa powder standard of SNI 3737:2009. The aim of this experiment was to evaluate the SME cocoa process production performance through Six Sigma analysis of the product to comply the standard requirements. The cocoa powder product was evaluated using three critical to quality (CTQ) parameters involving water content, color, and fineness. National standard determined the maximum water content value is $5 \%$, the color is brown or Agtron number 65 and minimum fineness percentage of particle $(75 \mu \mathrm{m})$ must be $99.5 \%$. This result explain the stability process of SME which is exceeding the control limit value of non conformity product. Its process capability showing the Sigma value of 2.6 with defect per million value was 126,667 . The CTQ parameters which contribute to the high non-conformity are fineness $78.95 \%$ and color $21.05 \%$. The rough cocoa powder or fineness affects the highest non-conformity related to the high fat content in cocoa cake as input process and can be revised by upgrading the pressing machine performance.
\end{abstract}

Keyword: cocoa, cocoa powder, small medium enterprises, Six Sigma

\section{INTRODUCTION}

Small medium enterprises (SMEs) are becoming new preferences for craft product processing managed by farmer group or small cooperative, including cocoa processing (Purba et al., 2018). Cocoa powder is one of cocoa intermediate products having large number of consumers in Indonesia, with many derivative products like sweets, cake, ice cream and cookies (Beg et al., 2017). Indonesian national standard set the pure cocoa powder as a product with mandatory standard stipulated with SNI 3747:2009 (Anoraga et al., 2019). Implementation and evaluation of this national standard in particular to SME's are required, to accomodate the obstacles that probably arising in its processing practices, such as consistency of fineness or acquired color of fully roasted powder evaluated by the processors (Herjanto, 2011). Food safety and narrow contamination is also another reason to mandatory cocoa powder standard to protect the consumer from healthy problems (Cain et al., 2019).

Cocoa powder is generated by pressing of cocoa mass, resulting extracted cocoa butter and cocoa cake as the rest. Grinding of cocoa cake will result in cocoa powder. 
Power capacity and operational setting temperature of pressing machine determine fat content in cocoa cake, which can affect to powdering process performance afterwards (Beg et al., 2017). Quality requirements of cocoa powder described on Indonesian national standard SNI 3747:2009 mostly include the aspect of physical appearance such as fineness, aroma, and color but also contamination of heavy metals and microorganisms (Singh \& Barak, 2019). However, the output product is not the only one parameter used to determine the effectiveness but also how its product specification comply to the consumer satisfaction. Quality parameters are also defined as both of how its product specification fulfill consumers satisfaction and preventing the product to become out of standard (Akhmad, 2018). Quality control are essential to maintain technical aspects of production process in conjuction with management interaction (Gleeson et al., 2019). The parameter of quality control consists of quality control of raw material, control of work in process and quality control of final product (Sangshetti et al., 2017).

Quality improvement tools are objected to check and analyze satistically to verify its product conformity to predetermined standard. Six Sigma is an improvement quality statistic tools using population deviation standard $(\sigma)$ to evaluate and control uniformity (Soemohadiwijoyo, 2018). The six number of Sigma ( $6 \sigma$ ) indicated the highest variance to be considered, therefore its non conformity probability product have to be controlled in 3.4 per million product capacity, or the cost expectation of poor quality not exceeding of $1 \%$ of the total revenue, higher than average value of $15-25 \%$ applied in established industry. Assesment method of Six Sigma was conducted by defining, measuring, analyzing, improving, and controling which can be explained as quantitative and qualitative results (Yadav $\&$ Sukhwani, 2016). The aim of this work was to study the out-of-specification product or defect per million opportunity from the SME's cocoa powder production in Jember with critical to quality (CTQ) defined by national standard parameters and to describe the process improvement to fulfill the SNI 3747:2009 requirements.

\section{MATERIALS AND METHODS}

\section{Sample Preparation}

Cocoa powder was obtained from cocoa powder production line in a SME at Jember with processing procedure as described by Mulato et al. (2010), applied for maximum capacity $200 \mathrm{~kg}^{\mathrm{day}}{ }^{-1}$ of raw beans with water content $7-7.5 \%$. Fermented cocoa beans originated from Jember regency were roasted in temperature $120^{\circ} \mathrm{C}$ for 25 minutes (with 15 minutes cooling time), grinded into particle size $350-400 \mu \mathrm{m}$ and pressed to separate cocoa butter with pressing machine to gain cocoa cake with fat content of $26.37 \%$. Powdering and sieving process were held on room temperature of $25^{\circ} \mathrm{C}$ in line with tempering machine by stored in refrigerator for 24 hours in $15^{\circ} \mathrm{C}$ before packing using sachet machine of $25 \mathrm{~g}^{\text {geach }}{ }^{-1}$. Samples were collected from production process every week for 20 times of samplings or replications, since December 2018 until May 2019. Each collection consisted of 10 sachets selected from random pack with 200 total samples. Production capacity reached 15,000 sachets per month and sample quantity was determined from Slovin Equation (Ryan, 2013).

\section{Physical Quality Evaluation}

Quality evaluation of cocoa powder according to Indonesian national standard, SNI 3747:2009 comply to three parameters of measurement consist of color, water content and fineness stated with the percentage of $75 \mu \mathrm{m}$ of particle size. These parameters were selected based 
on the critical control point of its process. The critical control point parameter in form of Critical To Quality (CTQ) in Six Sigma analysis.

\section{a. Color Evaluation}

A sachet of cocoa powder (25 g) was poured and spread into plate then its powder color was determined using Agtron Standard (Figure 1). The Agtron 65 was used as the control standard which color explained as brown (American type), otherwise Agtron 75 described as light brown, Agtron 55 as dark brown, and Agtron 45 as black very shinny (Pugash, 1995). SNI 3747:2009 point 4.1 does not clearly define the brown color in exact classification. The Agtron number standard adopted from coffee color evaluation is developed by Specialty Coffee Association of America (SCAA) to control the roasting condition or brown color of its powder. Agtron 65 are selected as the optimum roasting color of cocoa powder to obtain natural brown and to prevent the volatile aroma for being exposed excessively.

b. Water Content

The cocoa sample was evaluated according to SNI 3747:2009 standard poin 4.1 to control the water content from each production batch. Two grams of cocoa powder in porcelain cup with lid, was put in oven with setting temperature of $100 \pm 2^{\circ} \mathrm{C}$ until constant weight, then placed in desiccator for 30 minutes. Water content was calculated using Equation 1.

Water content $=\frac{(\mathrm{m} 1-\mathrm{m} 2)}{\mathrm{m} 0} \times 100 \% \ldots \ldots \ldots .1$

$\mathrm{m}_{0}=$ sample weight $(\mathrm{g})$

$\mathrm{m}_{1}=$ sample weight before drying $(\mathrm{g})$

$\mathrm{m}_{2}=$ sample weight after drying $(\mathrm{g})$

\section{c. Fineness Evaluation}

Ten grams cocoa powder were added with one gram of detergent and $20 \mathrm{~mL}$ of hot distilled water and stirred until dissolved. Hot distilled water of $280 \mathrm{~mL}\left(75 \pm 5^{\circ} \mathrm{C}\right)$ was added then stirred in hot plate stirrer. The solution was poured into 200 mesh $(75 \mu \mathrm{m})$ siever and rinse with one litre hot distilled water $\left(75 \pm 5^{\circ} \mathrm{C}\right)$, then rinse with $25 \mathrm{~mL}$ of acetone solution. The siever was moved into watch glass and dried in an oven for 45 minutes in temperature of $103-105^{\circ} \mathrm{C}$. The sample was then put in desiccator for 45 minutes. The residue content percentage was calculated by Equation 2 .

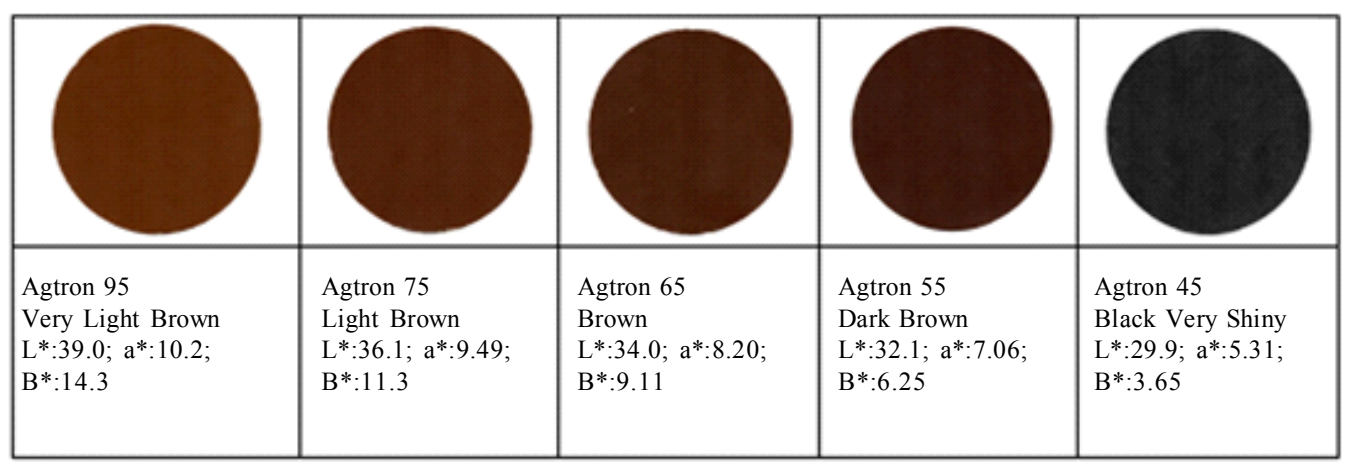

Figure 1. Agtron standards used in this study 
Residue content $(\%)=$

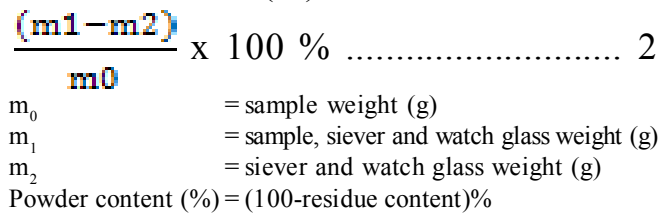

\section{Six Sigma Analysis}

Quality analysis using Six Sigma was conducted by determining the stability and capability process as quantitative tool, while unconformity analysis and improvement procedure treated as qualitative tools. Quantitative output was obtained by plotting the physical quality data of the samples into Pareto diagram and control chart (P-chart) involving upper control limit (UCL), lower control limit (LCL) and center line (CL), which were calculated from Equations 4, 5, and 6. Capability process was evaluated by calculating defect per million opportunity (DPMO) from Equation 6 and Sigma value from Equation 8. Qualitative output was presented in Ishikawa diagram (Tannady, 2015) or Fishbone diagram. Ishikawa diagram was developed to appoint out the cause and effect which accomodate to processing factor such as: man, method, machine, material and environment involved.

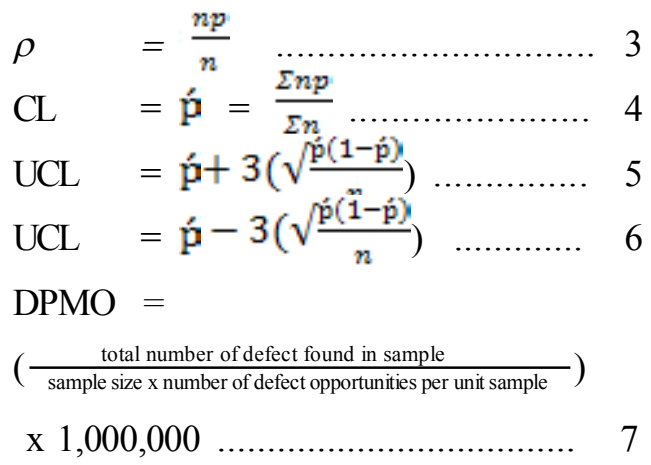

Sigma level $(\sigma)=$

NORMSINV $\left.\left(\left(10^{6}-\mathrm{DPMO}\right) / 10^{6}\right)+1.5\right) \ldots \ldots .8$

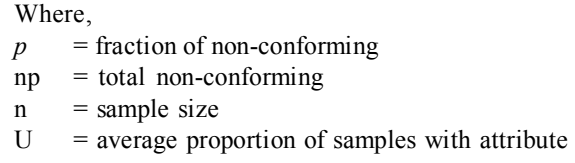

\section{RESULTS AND DISCUSSION}

\section{Stability Process}

Craft products are growing rapidly through the SME's in Indonesia along with the development of small scale machinery invention to utilize the raw material into the final product and arise the added-value at the bottom level of cocoa grower. Cocoa small scale processing, as performed by Manalu et al. (2017), utilize $150 \mathrm{~kg}$ of dry beans into final product including cocoa powder. Stability of cocoa powder process in this cocoa production was analyzed by critical to quality (CTQ) regarding to color, water content and fineness parameters as shown in control chart (P-chart) in Figure 2. Proportion of non conformity sample is beyond the control limit both the UCL and LCL, with highest proportion reaches 0.80 and lowest proportion is 0.20 . This result explains that the value of non-conformity sample from 20 samplings is out of control, but the exact parameter of CTQ contribute to the highest proportion have to be confirmed. This process situation regarding to Romdhane et al. (2016) called as point off limits with higher tendency, therefore require production improvement and intervention to adjust the process and to avoid the control limit.

The parameters of CTQ related to high proportion of non conformity sample was shown in Pareto diagram in Figure 3. The standard of SNI 3747:2009 requires the accepted cocoa powder specification which must be brown color, maximum water content is $5 \%$ by weight and the minimum percentage of fine particle $(75 \mu \mathrm{m})$ was $99.5 \%$. Color is critical to expose excessive volatile aroma 


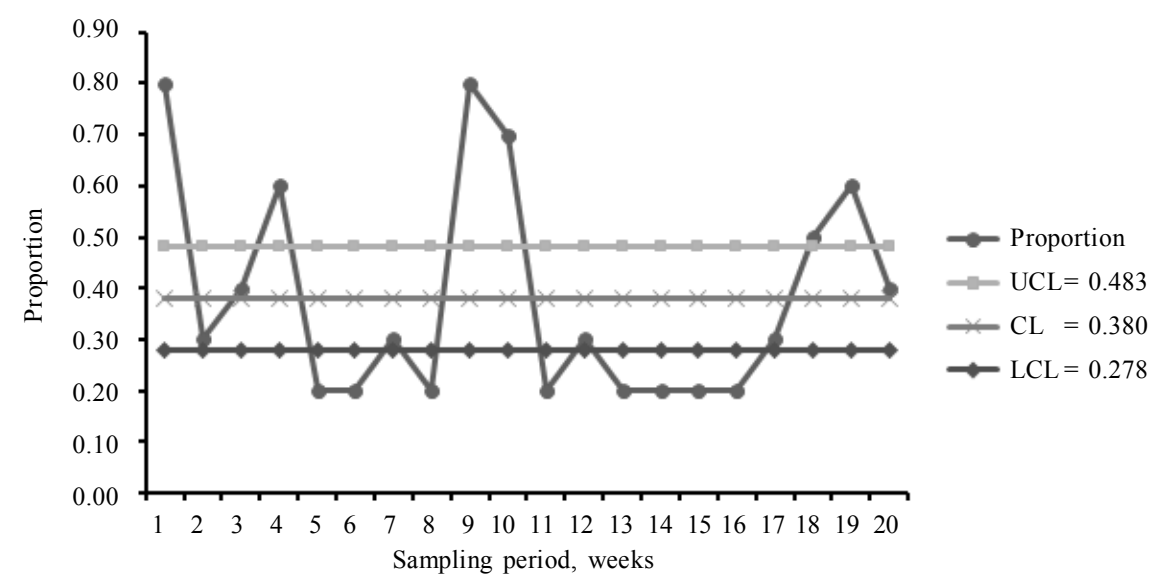

Figure 2. Control chart (P-chart) of cocoa powder process

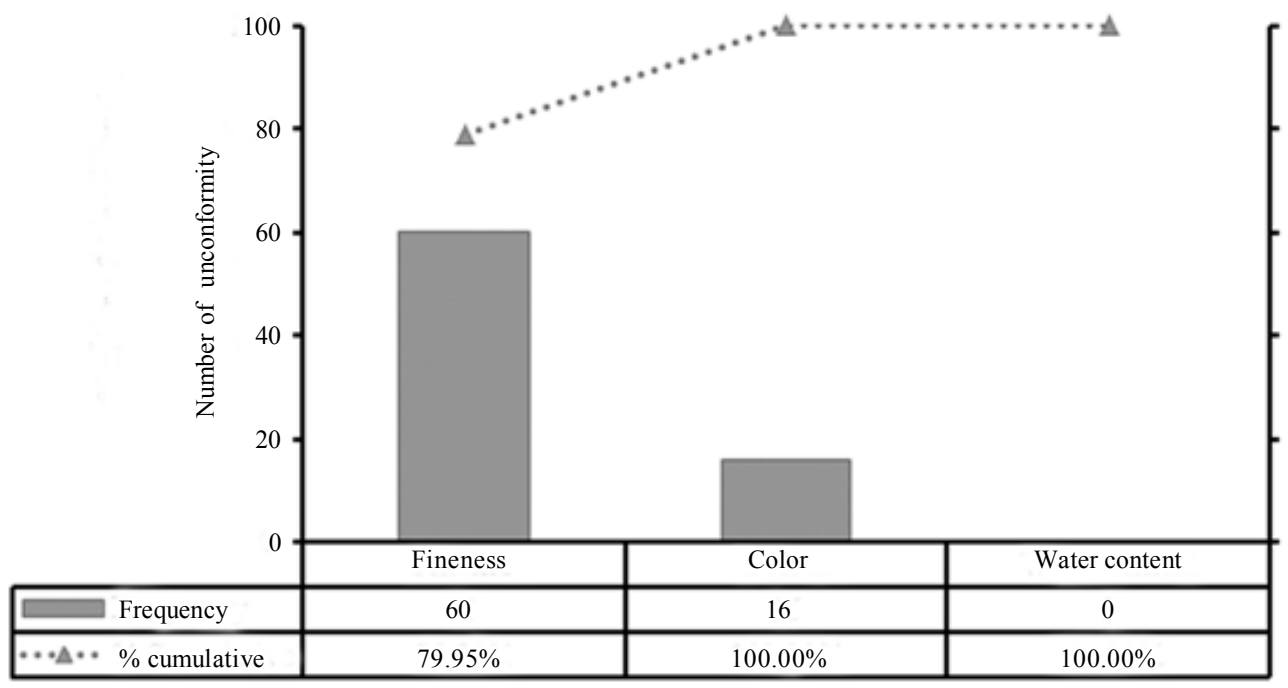

Figure 3. Pareto diagram of non-conformity cocoa powder product

during its roasting process, where the darker color might reduce the aroma quality of cocoa powder (Saccheti et al., 2016). High water content shows a deterioration effect during product storage such as the possibility of mold growth or chunk powder affected by its hygroscopic properties (Pereira \& Saint'Ana, 2018). The coarse cocoa powder give an effect on steeping session that it can not dissolved well in hot water. Figure 3 shows the non conformity sample majority contributed by fineness with percentage value gain $78.95 \%$ then followed by color with percentage value $21.05 \%$. Cocoa powder production using pressing process regarding to Miguel $\&$ Fettermann (2017) might gain $80 \%$ of losses around the capacity of 2 tons.month ${ }^{-1}$. This result stated the probability of non-conformity cocoa product in SME is stay high and may vary depend on its different processing sequence.

\section{Capability Process}

Capability process describes the company or SME performance to fullfill the standard requirements into the final product. Defect per million opportunity (DPMO) calculated from Equation 7 in conformity to color, water 
Firmanto et al.

Table 1. Comparison of DPMO value in local food industry towards SNI standard

\begin{tabular}{llccl}
\hline Product & \multicolumn{1}{c}{ Standard } & DPMO & Sigma (ó) & \multicolumn{1}{c}{ Reference } \\
\hline Water process & SNI 01-3554-2006 & 34,491 & 3.3 & Rimantho, D. \& D.M. Mariani, (2017) \\
Ice cream & SNI 01-3713-1995 & 176,030 & 2.4 & Bakti, C.S. \& H. Kartika, (2020) \\
Cooking oil & SNI 01-2901-2006 & 13,370 & 3.7 & Ginting, E.I. \& M. M. Ulkhaq, (2018) \\
Cake/bread & SNI 01-4309-1996 & 3,480 & 4.5 & Kurniawan, A., Sediono \& F. Adinna, (2018) \\
Cocoa powder & SNI 3747:2009 & 126,667 & 2.6 & Present study \\
\hline
\end{tabular}

content and fineness show the number of DPMO are 126,667 units per million product and obtain the Sigma level of 2,6. The highest Sigma level for $6 \sigma$ is comply to DPMO of 3.4 and the lowest Sigma level for $2 \sigma$ is comply to DPMO 310,000 (Stamatis, 2019). The Sigma level of cocoa powder processing compared to cake product according to Table 1 signify a big gap although both of them are classified as SME. However, higher capacity of production does not assure its high Sigma level such as reported in ice cream product (Bakti \& Kartika, 2020) and cooking oil (Ginting \& Ulkhaq, 2018). This cocoa powder capability process is rather low aligned to the common perform of average company in developing countries that could reaches $3 \sigma$ level (Antony et al., 2007). The main barriers to Six Sigma implementation in developing countries are issues related to culture and resistance to change (Douglas et al., 2017).

\section{Non-Conformity Production}

Non-conformity product of fineness (Figure 3) arise during processing in conjunction with operational procedure implementation and machinery. Operational procedure involves human as the operator, processing machine, material and environment which give the possibility that affect the non conformity. Detailed analysis of the cause and effect relation (Figure 4) explains the root causes such as low specification of raw material, not suitable machine specification, the operator ignore in controlling process condition, operational procedure, and processing room, regu- larly. Specification of cocoa cake as input material in cocoa powder processing still contained $26.37 \%$ fat which was higher than commercial defatted cocoa powder (around $10-12 \%$ ), in which become main problem during the process (Beckett, 2009). High fat content can be minimized by increasing the pressing machine performance. Environmental factor can may increase the water content during cocoa powder processing due to air humidity condition or room temperature fluctuations. Cocoa powder processing machine consists of cake grinding machine and sieving machine which was designed without temperature control appliances and not in accordance with high fat cocoa cake. However, cocoa cake as raw material may vary in terms of its fineness depending on the pressing machine type. Rough powder could affect its solubility that may even tolerable to consumer acceptance (Afoakwa, 2014).

\section{Production Improvement}

High fat cocoa cake as input material mostly contribute to problem of melting or chunking cake formation during powdering through grinding machine especially on disc mill type. Therefore, the high fat content of cocoa cake of rough powder has to be decreased (Petit et al., 2017). This process does not apply disc type grinder for powdering, but hammer and roll type so that the melting problem does not intensively occur. However, the melted fat could restrain the siever to pass out the fine powder. Cocoa cake as raw material contains $26.37 \%$ of fat which result in yield pressing process gain 


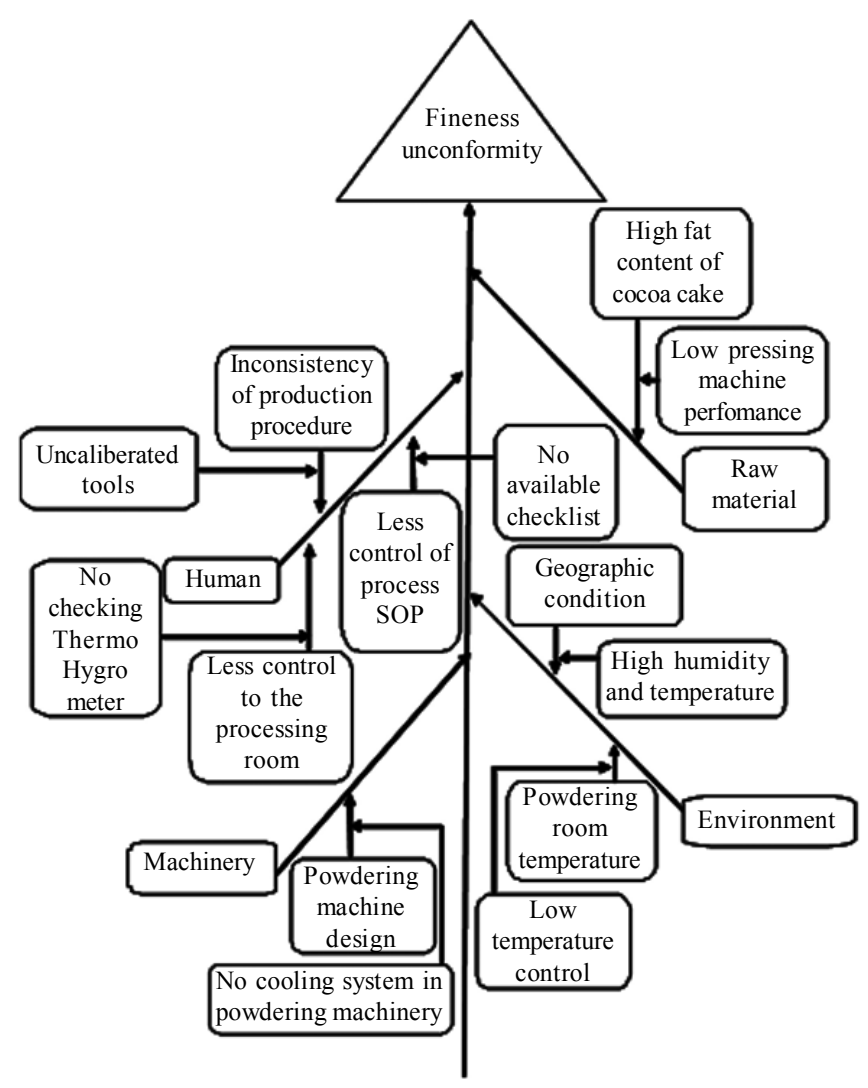

Figure 4. Ishikawa diagram of cause-effect of cocoa powder production

of $53.35 \%$ (oil/oil). Pressing machine in this process is operated in $20.7 \mathrm{MPa}$ using hydraulic press type in temperature $60^{\circ} \mathrm{C}$. Septianti \& Arif (2017), with the same hydraulic type of pressing machine, reported the final yield reached $57.86 \%$ (oil/oil) with fat content in cocoa powder obtain $25.13 \%$ for operational peressure $30 \mathrm{MPa}$ temperature $50^{\circ} \mathrm{C}$. This results reveal that the small scale processing equipped with low pressure of pressing machine $(<50 \mathrm{Mpa})$ result in high fat content cocoa powder, while industrial process can produce low fat cocoa powder less than 1013\% (Joel et al., 2013). Venter et al. (2007) also reported with higher temperature of $70^{\circ} \mathrm{C}$ with the same pressure of $30 \mathrm{MPa}$, produced a higher butter yield of $71.90 \%$ (oil/oil). In industry, cocoa liquor is pressed at $35 \mathrm{MPa}$ to obtain a yield of $73 \%$ fat. Pres- sures higher than $50 \mathrm{MPa}$ are used to obtain yields of $88 \%$ or higher. It is not expected to set pressure above $60 \mathrm{MPa}$ in small scale processing, because it will result in difficult maintenances (Minifie, 1989).

\section{CONCLUSIONS}

Non-comformity of cocoa powder used in this research mostly occupied by the rough powder problem which affected by high fat content in cocoa cake as input material. High fat content will become an obstacle in powdering and sieving machine, therefore the fine powder can not attain $99.5 \%$ as required in the SNI standard. Temperature of production room are also suggested to be controlled precisely by following the recommended operational procedure. 


\section{REFERENCES}

Afoakwa, E.O. (2014). Cocoa Production and Processing Technology. CRC Press, USA.

Akhmad (2018). Manajemen Operasi: Teori dan Aplikasi dalam Dunia Bisnis. Azkiya Publishing, Bogor.

Anoraga, S.B.; S. Wijanarti; I. Sabarisman \& A.R. Sari (2019). Optimization of temperature and time extraction for cocoa powder production on small scale farmers. Jurnal Ilmiah Rekayasa Pertanian dan Biosistem, 7(1), 85-94.

Antony, J.; F.J. Antony; M. Kumar \& B.R. Cho (2007). Six Sigma in service organisations. International Journal of Quality \& Reliability Management, 24(3), 294-311.

Bakti, C.S. \&H. Kartika (2020). Analisa pengendalian kualitas produk ice cream dengan metode Six Sigma. Journal of Industrial Engineering \& Management Research, 1(1), 63-69.

Beckett, S.T. (2009). Industrial Chocolate Manufacture and Use, $4^{\text {th }}$ Ed. John Wiley and Sons, United Kingdom.

Beg, M.S.; S. Ahmad; J. Kulsum \& B. Khalid (2017). Status, supply chain and processing of cocoa: A Review. Trends in Food Science and Technology, 66, 108-116.

Cain, N.; O. Alka; T. Segelke; K. von Wuthenau; O. Kohlbacher \& M. Fischer (2019). Food fingerprinting: Mass spectrometric determination of the cocoa shell content (Theobroma cacao L.) in cocoa products by HPLC-TOF-MS. Food Chemistry, 298, 125013.

Douglas, J.; D. Muturi; A. Douglas \& J. Ochieng (2017). The role of organisational climate in readiness for change to lean Six Sigma. The QTM Journal, 29(5), 666-676.

Ginting, E.I. \& M.M. Ulkhaq (2018). Analysis of ice cream product quality control with Six Sigma method. Industrial Engineering Online Journal, 7(1), 63-69.

Gleeson, F.; P. Coughlan; L. Goodman; A. Newell \& V. Hargaden (2019). Improving manufacturing productivity by combining cognitive engineering and lean Six Sigma methods. Procedia CIRP, 81, 641-646.

Herjanto, E. (2011). Mandatory application of SNI in industrial sector: Effectivity and aspects in its implementation. Jurnal Riset Industri, V(2), 121-130.

Joel, N.; B. Pius; A. Deborah \& U. Chris (2013). Production and quality evaluation of cocoa products (plain cocoa powder and chocolate). American Journal of Food and Nutrition, 3(1), 31-38.

Kurniawan, A.; Sediono \& F. Adinna (2018). Analisis pengendalian kualitas proses produksi kue lapis kukus surabaya berdasarkan metode Six Sigma. Statistika Journal, 18(1), 21-29.

Manalu, L.P.; M.Y. Djafar; T.Y. Wibawa \& H. Adinegoro (2017). A case study of SME cocoa by-pass processing in Luwu, South Sulawesi. Majalah Ilmiah Pengkajian Industri, 11(1), 51-60.

Miguel, V.C. \& D.C. Fettermann (2017). Use of DMAIC as a tool for loss reduction: an application in cocoa processing. Journal of Lean Systems, 2(1), 52-67.

Minifie, B.W. (1989). Chocolate, Cocoa, and Confectionary: Science and Technology. Chapman and Hall, London.

Pereira, A.P.M. \& A.S. Sant'Ana (2018). Diversity and fate of spore forming bacteria in cocoa powder, milk powder, starch and sugar during processing: A review. Trends in Food Science and Technology, 76, 101-118.

Petit, J.; F. Michaux; C. Jacquota; E.C. Montes; J. Dupas; V. Girard; A. Gianfrancesco; J. Scher \& C. Giani (2017). Storage-induced caking of cocoa powder. Journal of Food Engineering, 199, 42-53.

Pugash, M. (1995). The roast color classification system: Technology designed to advance the art and science of coffee roasting. Tea and Coffee Trade Journal, 167(7), 66-74.

Purba, H.H.; M.S. Maarif, I. Yuliasih \& A. Hermawan (2018). Single origin: the potential of 
market innovation for increasing the competitiveness of SMEs in chocolate industry in Indonesia. International Journal of Engineering Research and Advanced Technology, IV(5), 63-71.

Rimantho, D. \& D.M. Mariani (2017). Penerapan metode Six Sigma pada pengendalian kualitas air baku pada produksi makanan. Jurnal Ilmiah Teknik Industri, 16(1), $1-12$.

Romdhane, T.B.; A. Badreddine \& M. Sansa (2016). A new model to implement Six Sigma in small-and medium-sized enterprises. International Journal of Production Research, 55(15), 4319-4340.

Ryan, T. (2013). Sample Size Determination and Power. John Wiley and Sons, New Jersey.

Sacchetti, G.; F. Ioannone; M. De Gregorio; C. Di Mattia; M. Serafini \& D. Mastrocola (2016). Non-enzymatic browning during cocoa roasting as affected by processing time and temperature. Journal of Food Engineering, 169, 44-52.

Sangshetti, J.N.; M. Deshpande; Z.D.B. ZaheerShinde \& R. Arote (2017). Quality by design approach: Regulatory need. Arabian Journal of Chemistry, 10, S3412-S3425.
Septianti, E. \& A. Arif (2017). Effect of cocoa liquor temperature to the yield and fat content of cocoa powder fermented and unfermented cocoa. Jurnal Penelitian Pascapanen Pertanian, 13(1), 43-51.

Singh, M. \& S. Barak (2019). Cocoa and Chocolate Based Beverages. Scientific Publisher, Jodhpur.

Soemohadiwidjojo, A.T. (2018). Six Sigma: Metode Pengukuran Kinerja Perusahaan Berbasis Statistik. Penebar Swadaya, Jakarta.

Stamatis, D.H. (2019). Six Sigma Fundamentals: A Complete Introduction to the System, Methods, and Tools. CRC Press, New York.

Tannady, H. (2015). Pengendalian Kualitas. Graha Ilmu, Yogyakarta.

Venter, M.J.; N. Schouten; R. Hink; N.J.M. Kuipers \& A.B. de Haan (2007). Expression of cocoa butter from cocoa nibs. Separation and Purification Technology, 55, 256-264.

Yadav, A. \& V.K. Sukhwani (2016). Qualityimprovement by using Six Sigma DMAIC in an industry. International Journal of Current Engineering and Technology, 6(6), 41-46.

$$
* * 0 * *
$$

